CIVIC WARS 



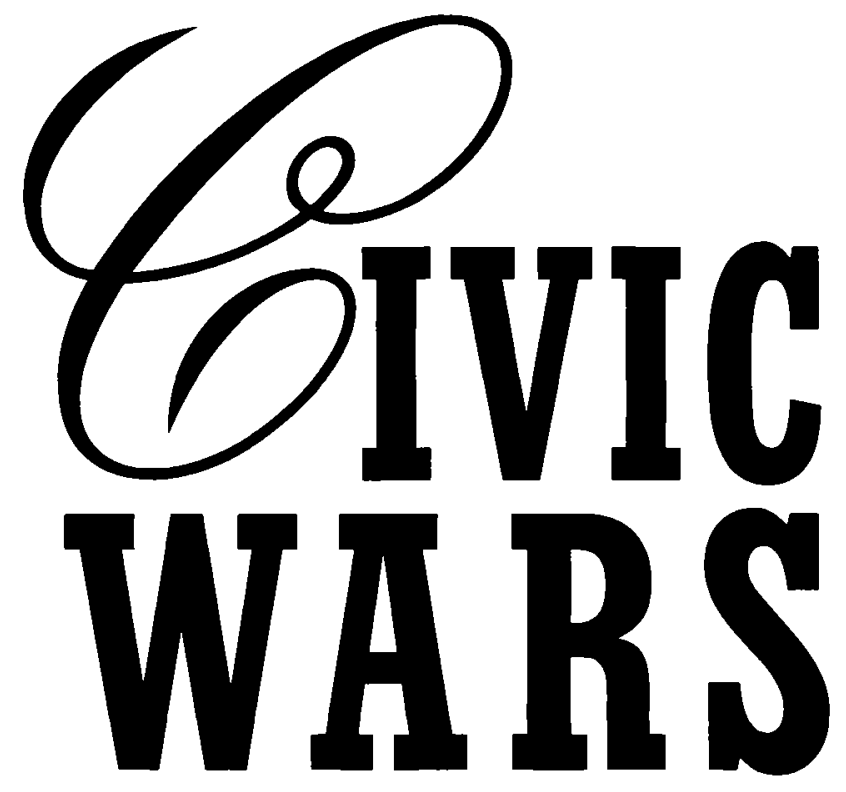

\title{
Democracy and Public Life in the American City during the Nineteenth Century
}

\author{
MARY P. RYAN
}


University of California Press

Berkeley and Los Angeles, California

University of California Press, Ltd.

London, England

(C) 1997 by

The Regents of the University of California

Library of Congress Cataloging-in-Publication Data

Ryan, Mary P.

Civic wars : democracy and public life in the American city during the nineteenth century / Mary P. Ryan.

p. $\mathrm{cm}$.

Includes bibliographical references (p. ) and index.

ISBN 0-520-2044I-7 (alk. paper)

I. Political participation-United States-History-19th century.

2. Political culture-United States - History - 19th century.

3. Democracy-United States-History-Igth century. 4. City and town life - United States - History - 19th century. 5. United States Politics and government-19th century. 6. New York (N.Y.)-

Politics and government-To 1898. 7. New Orleans (La.)-Politics and government. 8. San Francisco (Calif.)-Politics and government. I. Title.

JKi764.R9 1997

$320.973-\mathrm{dc} 20$

96-25630

CIP

The paper used in this publication meets the minimum requirements of American National Standard for Information Sciences-Permanence of Paper for Printed Library Materials, ANSI Z39.48-1984. 
For Anne 
